5-9 SEPTEMBER I 982

8th European Workshop on Drug Metabolism.

Universiteit van Luik, België.

Inlichtingen: Prof. J.E. GIELEN, Laboratoire de Chimie Médicale, Université de Liège, Bâtiment B23, B-4000 Sart Tilman par Liège I, België, tel.nr. 09-32 $41562480 / 8$ I.
I - 6 NOVEMBER I 982

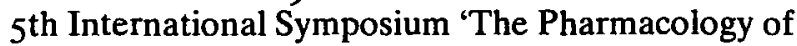
Thermoregulation'.

Mas d'Artigny, Saint Paul de Vence, Côte d'Azur, Frankrijk.

Inlichtingen: Prof. E. SchöNBauM, Peelkensweg 4 , 5428 NM Venhorst.

\title{
INGEZONDEN
}

Plaatsing van brieven in deze rubriek houdt niet in dat de redactie de daarin weergegeven zienswijze onderschrijft. De redactie behoudt zich het recht voor, ingezonden stukken te bekorten of te weigeren.

\section{Een slachtoffer van perfectie?}

Het overzicht van de regels van slagen en afwijzen, zoals neergelegd in de 'Voorschriften voor de onderdelen van het tweede gedeelte staatsexamen apothekerassistent' $6 \mathrm{e}$ gewijzigde druk (zie bijlage) bestuderend, leek het mij, dat de opstellers uiteindelijk zelf over hun ingewikkelde formuleringen waren gestruikeld. Wat blijkt nl.? Een kandidaat die een 4 haalt voor farmaceutisch rekenen, afleveren of receptuurkunde met 0 of I overpunten (totaal 40 of $4 \mathrm{I}$ punten) krijgt een herexamen op grond van regel $b$. met betrekking tot herexamens. Zou deze kandidaat echter 2 overpunten hebben behaald (totaal 42 punten) dan zou deze gezakt zijn. De kandidaat valt dan niet onder regel c. met betrekking tot slagen, noch onder $b$. met betrekking tot herexamens. En in alle andere gevallen is de kandidaat afgewezen (cursief gedrukt).

Een slachtoffer van de perfectie? Of ben ik toch nog gestruikeld?

Aruba, 22 september 1981.

A.J.W. RUNBEEK

\section{Bijlage II bij $V O / L M B / J Z 347.676$}

OVERZICHT VAN DE REgELS VAN SLAGEN EN AFWIJZEN

De kandidaat is geslaagd indien:

a. alle eindcijfers ten minste 6 bedragen of

b. één eindcijfet 5 en de andere eindcijfers waaronder dat voor het vak bereiden, afleveren, farmaceutisch rekenen en recepteerkunde ${ }^{1}$ ten minste 6 bedragen, of

c. één eindcijfer 4 en de andere eindcijfers waaronder die voor de onder $b$. genoemde vakken ten minste 6 bedragen en de som van de cijfers 42 of meer is, of

d. twee eindcijfers 5 en de andere eindcijfers waaronder die voor de onder $b$. genoemde vakken ten minste 6 bedragen en de som van de cijfers 43 of meer is.

De kandidaat is toegelaten tot een herexamen indien:

a. één eindcijfer voor een van de vakken afleveren, farmaceutisch rekenen en recepteerkunde 5 bedraagt en de eindcijfers voor de andere vakken ten minste 6 bedragen, of

b. één eindcijfer 4 en de andere eindcijfers waaronder dat voor het vak bereiden ten minste 6 bedragen en de som van de cijfers 40 of $4 \mathrm{I}$ is, of

c. één eindcijfer 3 en de andere eindcijfers waaronder dat voor het vak bereiden, afleveren, farmaceutisch rekenen en recepteerkunde ten minste 6 bedragen en de som van de cijfers $4 \mathrm{I}$ of meer is, of

d. twee eindcijfers 5 waaronder ten hoogste één voor een van de vakken afleveren, farmaceutisch rekenen en recepteerkunde en de andere eindcijfers waaronder dat voor bereiden ten minste 6 bedragen en de som van de cijfers 40 of meer is, of

e. één eindcijfer 4 , en één eindcijfer 5 waaronder ten hoogste één voor de vakken afleveren, farmaceutisch rekenen en recepteerkunde en de andere eindcijfers waaronder dat voor bereiden ten minste 6 bedragen en de som van de cijfers 41 of méér is.

In alle andere gevallen is de kandidaat afgewezen.

\footnotetext{
${ }^{1}$ Recepteerkunde $=$ bereiden en afleveren schriftelijk
}

\section{Naschrift}

Collega RUNBEEK is niet gestruikeld over de regels van slagen en afwijzen want zijn constatering is juist. In de praktijk blijkt het struikelen van kandidaten nogal mee te vallen omdat in voorkomende gevallen meer naar de geest dan naar de letter van het reglement wordt gehandeld. $\mathrm{Bij}$ de eerstvolgende herziening zal bij de staatssecretaris van Onderwijs en Wetenschappen worden aangedrongen op een gladstrijken van deze onvolkomenheid in het reglement.

's-Gravenhage, I9 oktober I98I.

Namens de Centrale
Commissie voor de
Opleiding tot apothekersassistent
H.A. SLOOT

Commissie voor de H.A. SLOOT 